\title{
WHOLE TIME AGENTS FOR LIFE INSURANCE
}

\section{By Edmund Strudwick, Jr.,}

The Atlantic Life Insurance Company.

In point of assets employed life insurance is the fourth largest business in the United States; and in amount of its contractural obligations it far exceeds any other business. In point of importance and beneficence to the country's population, it affects more individuals and a greater number of families than any other business. The spirit of altruism enters into it more largely than any other business, and yet it is the safest and its contracts are the soundest.

Life insurance is established upon fundamental principles expressed in mathematical formulae as intricate and exact as those used in scientific engineering. Although its product is standardized and competition as to price is almost eliminated, the demand for it must be created. For this purpose a field force of solicitors, men who go to other men to sell them insurance, is indispensable. The figures for 1916 are not available, but 185,750 life insurance salesmen were licensed in 1915. Is it not of vital importance that the biggest and best business in the country should be represented by men of the highest character? And is it not an impelling duty of those who direct that business to do all in their power to elevate the character and develop the efficiency of its representatives in the field? What type of men then should these solicitors be? And how should they conduct their work?

\section{Characteristics of an Ideal Salesman}

The character of a salesman is largely determined by the character of the business he represents. No argument is necessary to establish that life insurance is a science and that work in life insurance, whether in the office or field, is the practice of a profession. Evidently in the pursuit of a science and the practice of a profession a high class of man is necessary; and if in either office or field a higher type is needed, more in the one place than in the other, preference in the assignment should be given the field. The most apparent reason for this distinction is that the field man comes in contact with the public, personifies the company to them, and 150 
consequently his acts in effect are the company's and his reputation the company's also.

The ideal life insurance agent has been sketched in theory so often that no more than a glance at his qualifications need be given here. In general, he should know the principles underlying life insurance: he should understand the construction of the mortality tables; the necessity for a reserve, and the difference between preliminary term, select and ultimate, and full terminal reserve; the relation of net premium and compound interest to this fund; the elemental parts of a gross premium; and the distinction between pure endowments, annuities, whole life insurance, term insurance, and endowment insurance. He should be familiar with the history of life insurance: the beginning of the business, and its development from a speculative phase to a legitimate business; the failure of assessment associations; the unsoundness of all insurance schemes not based on the maintenance of adequate reserves; the present enormity of the business; and the opportunities for its future development. $\mathrm{He}$ should have a fair knowledge of the law of insurance, particularly regarding contracts and agency, and should acquaint himself, as far as possible, with the insurance statutes and the rulings of the insurance department of his state. He should have accurate knowledge of his own company-its assets, surplus fund, amount of insurance in force, and disposition in dealings with policyholders-in short, have accurate knowledge of all its strong points and the ability to answer any adverse criticism which may be directed against it. It is also important that he should inform himself as far as possible about other companies with which he will come in competition. Most essential is an intimate familiarity with the various policy contracts of his company and with each clause and provision contained therein, and an unfailing ability to determine his prospect's needs with a view to fitting the contract to him, both as regards the prospect's own personal condition and the requirements of the beneficiary. Here again a knowledge of the contracts of competing companies is necessary.

The foregoing knowledge or information is what the ideal agent will use in selling insurance, but if he does not use it properly, the effectiveness of the result is seriously impaired. Hence the ideal agent should have other qualifications. He should have pleasant address, engaging manners, tact, consideration for the business and 
time of others, and the faculty for creating a condition of mutual human interest between himself and his prospects. He should establish in his community a reputation for civic pride, public spirit, and neighborliness in order that he may command respect and attention. Above all, he must be a firm believer in the necessity for life insurance, in the application of it to a variety of needs, in the unending good it does and can do, and in his own sacred mission in persuading as many people as he can to become insured.

No one will claim that insurance would prosper if none other than such men as filled the foregoing requirements were licensed as agents, because there would be so few of them. But, on the other hand, no one will deny that, if men of this class could be gotten in sufficient numbers, life insurance would soon be the most venerated institution of man's making, and the most potent factor in hastening universal economic independence.

\section{Part-time vs. Full-time Men}

It should be borne in mind that this sketch is of the ideal agent; but it is by no means necessary that a solicitor should be so thoroughly trained along technical lines or so fully furnished with historical information to become a successful solicitor and render efficient service both to his company and the public. No argument seems necessary, however, to show that the continual elevation of the agent's standard is desirable; but argument has always been necessary to show that each individual agent, if -he would contribute to the raising of the standard, should give his whole time and attention to the business. This brings up the question of the wholetime versus the part-time agent. A modern and eminently practical angle from which to compare these two classes of agents, say the champions of the full-time man, is that of service. When great mercantile concerns have reduced prices to show a minimum of profit, have improved quality to the limit of ingenuity, have done all to put their products ahead of their competitors and still need a further bid for popular approval, they develop their capacity to serve their customers with a variety of concessions and accommodations. Needless to say, their salesmen are full-time men. How much more important, it is argued, that a business dealing in such a vital commodity as life insurance should serve its customers in the most efficient manner. A misrepresentation, a delay in the 
delivery of a policy, the inability to advise correctly, or absorption in some line of work other than life insurance on the part of the agent, may work much hardship on an applicant or policyholder and may prejudice an entire neighborhood against the institution of insurance.

On the other hand, there are those who agree in the responsibility placed upon the insurance agent, and concede the dependence of the public upon him, but, for that very reason, argue that no one should be denied a license to solicit. They contend that every agent who does anything at all does just that much towards the furtherance of life insurance education and the increase of the amount of insurance in force.

Such lines of reasoning, of course, devolve finally into personal opinions, and it seems that personal opinions constitute the bulk of authority on this subject. With this limitation of reference in mind, a circular letter was prepared and sent to a selected list of general agents for the purpose of collecting as many individual opinions as possible on what were deemed the most important phases of the part-time agent problem. Eighty-two answers were received, seventy-two of which were usable. These came from twenty-five states, the District of Columbia, and Canada, and were received from the representatives of twenty-four insurance companies.

The first question asked was: Do you appoint part-time agents? Seventy-one answered this question, fifty-two by "yes" and nineteen by "no," thus showing a rather strong minority of over 28 per cent who do not favor the appointment of part-time men.

Question number two was: If so [if you appoint part-time agents], about what proportion of your force do they comprise? Forty-two answered this question, and the proportion ran from 2 per cent as a minimum to as high as 90 per cent in one case. Not knowing the number of men in each agency, it is difficult to compile significant ratios. But, for the sake of illustration, if the agencies averaged twenty men each, the ratio of part-time to whole-time men in the forty-two agencies responding is eight to twenty.

The third question was: And if so [same condition] about what proportion of business in your agency do they produce? Forty-two answered, showing a variation of from 2 per cent to 70 per cent. Again, a significant deduction is difficult, but, supposing that each of the twenty agents in an agency produced $\$ 50,000$ of business, the 
ratio of the business produced by part-time men to that produced by full-time men is $\$ 190$ to $\$ 1,000$. Combining the answers to questions two and three, 40 per cent of the agency force produced 19 per cent of the business.

Question four was: Is the renewal experience of the insurance written by them satisfactory? Above or below normal? Out of fiftytwo answers to this query, forty-two claimed that the business written by part-time men renewed normally or above normal; while nine contended that it renewed below normal.

The fifth question was: Have a considerable number of your good agents developed from part-time men? Fifty-seven answered, twenty-five in the affirmative and thirty-two in the negative.

In answer to the sixth question: Do you consider the part-time agent $a$ help or a hindrance in bringing about a pleasanter relationship between agent and policyholder? Twenty-six considered him a help and twenty-four a hindrance. A noticeable number considered him a help in country districts and a hindrance in metropolitan districts. These replies are not included in the above fifty.

The last question was: If the part-time man constitutes a problem in your territory, what solution do you recommend? Nine replies were written in such a general way that they hardly lend themselves to collation. Forty-six replies, however, specifically recommended a definite thing: seven favor the appointment of part-time men as apprentices with a definite contractual understanding that they will agree at the end of a specified period to accept a full-time contract or have their part-time contract canceled; seven are for cooperation on the part of the companies to appoint only whole-time men; fourteen are for an individual determination on the part of the general agents absolutely to eliminate part-time men; and sixteen are for retaining them in rural districts and discontinuing them in urban districts. One very positive reply comes from Oklahoma, giving the opinion that the insurance commissioner should have and use power to refuse licenses to all but full-time men; and a Massachusetts agent would like to see the legislature pass a law prohibiting all but full-time men from selling life insurance and rather expects some such action by the next Assembly.

The answers given are more than significant. Twenty years ago the term "part-time agent" had little or no meaning; everybody accepted him as a matter of course. He began gaining notoriety 
when the public determined to do away with rebating, misrepresentation, and twisting. It was found that the "spotter" and the "one case" man were the greatest offenders along these lines. This type has about disappeared, but the fact that nineteen out of seventyone picked general agents refuse even to consider the appointment of part-time men must signify some fundamental objections to the less than full-time agent.

Probably their refusal to appoint such men is based upon an experience similar to that of a very prominent general agent who has calculated that the agents he has appointed during his career have cost him an amount which, divided by the number of producing agents finally developed, makes these producing agents represent an average investment of $\$ 3,000$. Certainly, the part-time man if the general agent spends time and money upon him, becomes a permanent investment, and if he leaves the company he yields no dividends on the investment and takes with him the hope of the repayment of principal invested. Another prominent general agent, writing in the Western Underwriter under date of November 11, 1915, says in part: believe:

We do not license bank officers or clerks, as part-time agents, because we

First, that it is against modern methods in business.

Second, that the practice is unbusinesslike.

Third, that no banker can act as a life insurance agent and take a commission upon a life insurance transaction without in every such instance being unethical and in all too many cases, absolutely abusing a confidential relation.

These reasons deal with what is considered a high type of parttime men and is the more impressive on that account. Many addresses have been made at agency conventions, and many articles have been published in insurance journals expressing in most emphatic terms the undesirability of the part-time worker as an insurance agent. It is men with such ideas who have injected into the answers to these seven questions a tone of dissatisfaction with part-time men. Strong voices are raised in protest, however, against discrimination in favor of the full-time agent. A very judicial article in the Western Underwriter of October 21, 1915, works out as its theme: "Every man aiding in procuring an application participates in the earning and should be paid in proportion to the value of his service." 
The drift of opinion among general agents was probably accurately expressed in a personal interview with a North Carolina general agent who said in substance, "So long as other agents are appointing part-time men in my territory, I cannot afford to take a stand myself. The only way to eliminate part-time men is for all the general agents in any given district to enter into an agreement not to appoint such men as agents."

Conventions and meetings of various life underwriters' associations have staged acrimonious debates regarding the part-time agent, which have resulted in many cases in resolutions being passed and recorded against the employment of the part-time man. It would be hard to escape the conclusion that the trend of feeling among general agents is distinctly against the man who does not devote his entire time and energies to insurance, the notable exception being the local representative in a sparsely settled country district.

\section{The Atritude of the States}

Circular letters were also addressed to the heads of the insurance departments of all the states. In this instance, also, the response was most gratifying. Forty replies were received, and in several cases copies of statutes, court decisions, and clippings accompanied the letters.

To the first question: Do the statutes of your state prohibit the licensing of part-time agents or restrict their activities in any way? thirty-nine answers were received, one in the affirmative and thirtyeight in the negative, the one exception being Missouri.

The second question was: Do the statutes give the head of the department discretionary power in issuing licenses? Twenty-one answered "yes," and eighteen "no." The discretion allowed consisted, in the majority of cases, in the privilege of refusing a license to an applicant who had violated the insurance laws, or, from some other cause, had acquired an unsavory reputation in insurance circles. No reference is made to any distinction between fulland part-time men.

To question three: Do the statutes provide for the investigation by the insurance department of an applicant for an agent's license? ten answers were received in the affirmative and twenty-nine in the negative. The investigations provided for ranged from a perfectly 
routine set of interrogatories in connection with the application for license signed by the company only, to a more searching inquiry to be signed by the prospective agent and countersigned by the applicant company by way of endorsement.

To the fourth question: If not, do they require a certification of character from the company the agent purposes representing? thirtyfour answers were received, six answering "yes" and twenty "no." But several of those answering "yes" were states in which the insurance department as well investigated the applicant. In other words, the departments investigate through the companies.

Question five, with one exception, was answered in the negative. It was: Do the statutes in any other way refer to part-time agents? The question would have elicited significant replies only if the statutory articles referring to part-time men had been given, which, in this case, was not done.

Only six departments out of thirty-two favored the unrestricted licensing of part-time agents, as was brought out by question six which reads: Does your department favor the unrestricted licensing of part-time agents? The reason given in one of these cases was that it seemed rather partial and even autocratic to force a man to devote his whole time to the pursuit of a particular profession or, in event of his desiring to devote only a part of his time thereto, to refuse him a license altogether.

By answering "yes" to question seven: Does your department or legislature contemplate taking steps to regulate the pari-time agent? two departments signified an active interest in the part-time question. In one state an agency qualification law is contemplated, in another an agency qualification law is to be recommended to the legislature which is convening as this article goes to press.

From the answers given to these questions, one conclusion, at least, stands out prominently: The heads of the insurance departments do not consider the agency problem one to be settled by them through legislative statutes or departmental rulings. This fact has been forcibly brought out at a number of Insurance Commissioners' Conventions where, to every attempt to force the body to commit itself to some definite expression of opinion and course of action on the part-time agent question, the majority of the membership has always replied that the agency problem, whether whole- or part-time, was essentially the companies' problem, and that it should be set- 
tled by them on an economic basis and in a spirit of coöperation, without legislative assistance.

This stand of the departments seems justified from a purely common-sense as well as from a legal point of view. One of the few cases at law ever decided upon the point is William Hansen $v$. North British and Mercantile Insurance Company in the New York Court of Appeals. Briefly stated, Hansen sold two policies for the company and requested his brokerage commission. The company refused him this because he had no brokerage license. The insurance department, in turn, had refused him a license because the statutes provided that a broker could only be licensed when he engaged "principally in the insurance business" or "in connection with a real estate agency or real estate brokerage business." This applicant for a license practiced law as his chief profession. In deciding for Hansen, Judge Gray said in part,

If the legislative act overstepped the limits, within which the legislature may regulate and restrict the business pursuits of the citizen, then it was violative of the plaintiff's constitutional rights and was inoperative to deprive him of the right to his brokerage.

The appelate division, in the first department, has held the statute to be unconstitutional legislation, and I think that we should affirm its determination.

There is no good reason, and no public interest can, conceivably, be subserved in prohibiting persons from conducting the business of an insurance agent or broker, in connection with any other lawful business, or occupation in which they may be engaged.

If it is unconstitutional to prohibit the licensing of part-time agents, the insurance departments, however, have no such bar to recommending to every state an agent's qualification law which would recognize the social importance of the life insurance profession and be based upon an appreciation of the peculiar relationship of responsibility and trust between the solicitor and the policyholder. This law, moreover, would increase its usefulness by requiring careful investigation of an applicant for an agent's license and by giving the head of the department discretionary power in the issuance of licenses. Such machinery would go far towards guaranteeing that only life insurance salesmen of average and higher character, ability, and purpose would secure licenses. The part-time agent problem would then disappear to a large extent, without being directly legislated against, because, if part-time men could not meet the 
requirements, they would not receive licenses. Moreover, if they could meet the requirements, there would be little inherently wrong with them, and again the problem would be minimized. The New York application for an Agent's Certificate of Authority has printed in red upon its face:

The department requires that there shall accompany each application for an Agent's Certificate of Authority evidence that the company or its representative has investigated the qualification of the applicant to act as its agent. A written report of such investigation, giving the facts as to the character and experience of the applicant, countersigned by the officer who approves the application, must be attached hereto.

And the department uses its discretion in issuing the license as is shown by the following quotation outlining their regular practice:

The regular practice of this department is to issue such licenses only to men who intend devoting their entire time to the business of soliciting life insurance. This is a rule of the department which is not varied from excepting in cases where applications coming from men who propose to devote only a portion of their time to this business are accompanied by the strongest recommendations as to competency and trustworthiness, and also by some definite assurances to the effect that the applicant intends ultimately to engage exclusively in the business of soliciting life insurance, and that his application as a part-time man is made in order to enable him to withdraw gradually from his present occupation.

Such an attitude on the part of a department must go far totowards eliminating part-time agents, because upon application for renewal of license, the truth of their previous statements of purpose to become full-time men can be verified.

\section{The Atritude of the Companies}

The next point to be considered, and by no means the least important, is the attitude of the companies themselves towards the part-time agent. No attempt has been made in the preparation of this article to circularize them for this information. The reason for omitting to do so was that the majority most probably would have replied that the matter was one for settlement by their general agents and not by the home office. But can they escape all responsibility and avoid all embarrassment by such an attitude,assuming that the problem is embarrassing and involves executive responsibility?

In an address delivered at the World's Salesmanship Congress 
in Detroit, July, 1916, the President of the National Association of Life Underwriters estimated that 60,000 agents cancelled their contracts with life insurance companies in 1915. In a great many cases these were men who had received advances, been paid salaries, traveled to the home office at the company's expense, or involved the company in the expense of hunting them up and sending representatives to see them, and, finally, had probably run up rent bills and expense accounts. He states that in all cases the company at least had to pay for the license, a rate book, and supplies. "The president of one of our largest fire insurance companies," he said, "valued each fire agent at $\$ 250$. These 60,000 failures, therefore, cost a figure that must be admitted as most conservative-- $\$ 6,000$,000." "It is a fact," he asserted in another part of his address, "that large numbers of these agents are part-time agents." Thus the companies are put to an actual financial loss by part-time agents which is far from made up in profits from the first premiums on whatever business they may have originated. But in the address the largest loss to life insurance through these 60,000 agents is outlined thus:

Assuming that the failure of each one of these agents adversely advertised life insurance as a discouraging business, deterring others from taking it up because of their failure, to an average, of four others, kindred and friends, it would mean 300,000 persons looking discouragingly at life insurance as a business.

Assuming that each one of these before giving up the business interviewed during the average of perhaps one year's time that these agents were nominally under contract, even fifty people, it would mean that $3,000,000$ persons, less duplications, had life insurance presented to them probably in an ineffective, unintelligent and inexperienced, if not bored method.

The company, it would seem, therefore, from an executive standpoint, has very little reason for wanting part-time agents on its books.

\section{The Views and Needs of the Public}

Finally, does not the whole problem come back to the insuring public? What do they need? And what do they demand? As they become more throughly educated in insurance they require more expert salesmanship; they make inquiries which necessitate a specialist's answer: they demand a quality and quantity of service which no part-time man can give. The day is passed when the average prospect is taken in blindly by catch phrases and smooth 
talking. He knows today that he is entering into a legal contract with a responsible financial institution and he expects the representative of that institution to be in all respects worthy of the company he represents, and the contract he recommends. Life insurance is more and more fitting itself to the complicated requirements of present day involved economic life, and the public will not be satisfied by the inefficient service that must necessarily be rendered by a part-time man.

\section{ConcLusion}

What definite conclusions can be derived from the investigation? First, that among general agents there is a decided trend towards the ultimate elimination of the part-time agent; second, that the heads of the insurance departments, while not attempting any agency adjustment through legislative channels, are, nevertheless, in a few cases using their discretion in the licensing of part-time men and, more frequently, requiring a more or less searching investigation of the applicant; third, that the companies themselves are experiencing annually, through the part-time men, a large direct loss and a larger indirect loss; and fourth, that the insuring public have arrived at a point where more expert and efficient service than parttime men can render, is necessary to enlist their interest and secure their patronage.

In the metropolitan districts, especially in the larger cities, all part-time men could be discontinued without seriously affecting the volume of production. The field in such districts lends itself naturally to intensive soliciting and can be much more thoroughly and efficiently covered by whole time men working without the interference of part-time men. The country districts, however, are not yet ready for the elimination of the part-time man. He fills a real need there. Where, on account of sparse and scattered population, a man devoting all of his time to soliciting would have to travel long distances and cover a large territory, thus being unable to establish a personal relationship with his policyholders and to keep them interested in their insurance, a man, devoting only a part of his time to insurance and supplementing with other business to fill out his income, could supply the insurance needs of his immediate community and keep in close personal touch with all his clients. As such communities, of course, become more densely populated, 
their need for part-time men, at best a compromise with temporary conditions, disappears. Since by far the greatest bulk of insurance is written in the more densely populated communities and since these communities are increasing continually in number and extent, the supplying of them with full-time insurance agents to the exclusion of part-time agents is an immediate and constant problem.

The present investigation furnishes these suggestions for definite action toward the solution of the problem: a concerted action on the part of the insurance departments to have agency qualification laws passed which will require a searching investigation to be made of all applicants for licenses, and will grant to the heads of the departments discretionary powers in the issuance of licenses; a demand by the public upon the insurance companies and their agents for a quality of service to which they are justly entitled and which can be furnished only by scientifically trained experts devoting their whole time to the business; and finally a determination by mutual agreement among the several insurance companies and the general agents of the companies to coöperate vigorously in discontinuing the appointment of part-time men in every community where full-time men can more efficiently perform the work.

If, as it seems, the gradual elimination of the part-time man is a thing to be effected, the insurance departments and the insuring public should do their part in hastening this accomplishment. But if actual and immediate results are to be obtained, too great stress cannot be laid on this final recommendation. The companies and their general agents have it in their power to cancel every part-time contract at any time they may determine upon. They are prevented only by lack of coöperative action and by considerations of expediency. In the last analysis the ultimate solution of the problem must come through and by them. 